\title{
Detection of vitamin B12 levels with the aid of some hematological and biochemical parameters that are more sensitive
}

\author{
Süheyl Asma1, Ferit Erdoğan1, Aydan Ünsal1, Can Boğa1, Hakan Özdoğu1, \\ Çiğdem Gereklioğlu¹, illknur Kozanoğlư ${ }^{1}$, Erkan Maytalman1
}

\begin{abstract}
Vitamin B12 deficiency is a health problem, which is usually seen in elderly patients and results in hematological and neurological disorders. In this study, we aimed to investigate the serum levels of vitamin B12 could represent the real tissue levels with considering some hematological and biochemical parameters. 128 patients whose vitamin B12 levels have been detected to be low and their ages are ranged from 16 to 90 , have been investigated. Fifty three of them were females. Complete blood counts, antiparietal antibody (APA), homocysteine levels, peripheral blood smear evaluations and findings of gastroduodenoscopy were assessed. Mean volume of erythrocytes has been found as $107 \mathrm{fl}$ in patient group (group 1), in which vitamin B12 level has been detected lower than $60 \mathrm{pg} / \mathrm{mL}$. The higher homocysteine values in $85 \%$ cases, neutrophil hyper-segmentation in $82 \%$, atrophic gastritis in $53 \%$ and APA positivity in $\mathbf{4 7} \%$ of cases have been detected. The average of age has been detected as 65 in this group. High level of homocysteine has been present in $44 \%$ of cases and MCV has been $91 \mathrm{fl}$ in group 2, in which the vitamin B12 levels are between 61-100 pg/ mL. In group ( group 3), in which vitamin levels are between $101-140 \mathrm{pg} / \mathrm{mL}$, elevated homocysteine levels in $27 \%$ cases and MCV as $89 \mathrm{fl}$ have been detected. In group 4 , in which vitamin levels are between $141-178 \mathrm{pg} / \mathrm{mL}$, homocysteine elevation in $16 \%$ of cases and MCV as
\end{abstract}

KEY WORDS: Vitamin B 12, homocysteine, anti parietal antibod

\section{INTRODUCTION}

The diagnosis and treatment of the megaloblastic anemia regarding vitamin B12 or folic acid deficiency are important. The vitamin B12 and folic acid deficiency are a group of diseases whose their diagnosis are easy and the cost of their treatments are fairly lower. The delays in the treatment could lead to series complications such as anemia, irreversible neurological impairment, neurological tube defects and thromboembolism (1-3). The deficiency of vitamin B12 is more prevalent than the previously known in the population $(4,5)$. The prevalence in elderly people is approximately between the 10 and $20 \%$.

However about $5-10 \%$ of the patients with vitamin B12 deficiency is asymptomatic. The classical clinical findings and signs are the neuro-psychiatric symptoms, glossitis, macrocytic anemia and other cytopenias. For the diagnosis, the levels of serum vitamin B12 should be measured and in addition, homocysteine and methyl malonic acid levels should also be detected for correct interpretation of vitamin B12 levels (6).

The serum level of vitamin B12, which is one of the current methods of diagnosis, is known not to represent the real tissue level (7). In the serum of patients with vitamin B12 deficiency, the anti parietal cell antibodies (APA) in $90 \%$ of cases, anti intrinsic factor antibodies in $60 \%$ of cases and anti thyroid antibodies in $40 \%$ of cases are present in the serum of patients (8). The measurement of the methyl malonic acid and homocysteine levels that have been elevated in the early period of vitamine B12 deficiency is a more sensitive method for screening the vitamin B12 deficiency. Since the elevation of at least one metabolite is $94 \%$ sensitive and $99 \%$ specific.
AFFILIATIONS

1Başkent Üniversitesi, Tıp Fakültesi, Adana, Türkiye

CORRESPONDENCE

Aydan Ünsal

E-mail:

aydanunsal@hotmail.com

Received:

13 April 2010

Revision:

25 May 2010

Accepted:

12 June 2010 
Schilling test which has been utilized for the detection of pernicious anemia has usually been replaced with the serological detection of antibodies to intrinsic factor and parietal cells (9).

Many unnecessary treatments and interventions might be performed in patients without clinical signs of findings when their serum levels of vitamin B12 have been found to be lower in the clinics. In the present study, we aimed to find the more significant vitamin B12 levels with hematological and biochemical tests in terms of detecting the deficiencies in the cases whose serum vitamin B12 levels are measured lower than reference values.

\section{MATERIALS AND METHODS}

\section{Selection of the cases and design of the study}

Of the patients that have been applied to our center for anemia between April 2005 and November 2007 or are referred to hematology consultation for having lower vitamin B12 levels, a total of one hundred fifty eight cases whose ages are between 16 and 90 and fifty three of those are female; have been retrieved retrospectively for the information regarding headings of diagnosis/referring diagnosis, cause of application, physical examination findings, assessment/plan laboratory data, anti parietal antibodies result, radiology/endoscopy/ pathology, consultation, etiology, treatments and advises heading from computer software (Avicenna HBSY, Ankara, Turkey) for the nutritional anemias. The patients with the combined iron deficiency, folic acid deficiencies or thalessemia carriers have been excluded from the study.

Patients have been categorized into four groups based on their vitamin B12 levels. The 34 patients whose vitamin B12 levels are lower than $<60 \mathrm{pg} / \mathrm{mL}$, their ages ranged from 32 to 90 and 13 of them are females constituted the group 1 one; the 32 patients, whose vitamin B12 levels are between 61 and 100 pg $/ \mathrm{mL}$, their ages ranged from 19 to 87 and 14 of them are females constituted the group 2, 29 patients one, whose vitamin B12 levels are between 101 and $140 \mathrm{pg} / \mathrm{mL}$, their ages ranged from 21 to 88 and 12 of them are females constituted the group 3, 28 patients, whose vitamin B12 levels are higher than 141 to $178 \mathrm{pg} / \mathrm{mL}$, their ages ranged from 16 to 62 and 14 of them are females constituted the group 4. A total of 128 patients have been included into study. Demographic information and clinical findings of the patients have been recorded.

\section{Laboratory tests}

The complete blood count, thyroid function tests, folic acid and homocysteine levels and the peripheral blood smear evaluations have been assessed in the venous samples of the peripheral blood that have been drawn from the fasting patients. The preparations have been used to detect the auto-anti bodies against to parietal cells commercially (Euroimmun, AG, Germany). They have been incubated with $1 / 10$ patient serum for initial dilution. Then they have been incubated with IgG FITC and the parietal antibodies have been detected with immune fluorescent microscope (Euro star, Euroimmune, AG, Germany). The reference range has been detected as the 179 $883 \mathrm{pg} / \mathrm{mL}$, with the chemiluminescent microparticle immune assay (Abbott Laboratories, Abbott Park, IL, USA) in the Arcitect device. The homocysteine levels have been measured in the AXYM device (Abbott park, IL, USA) with the fluorescence polarization immune assay method and reference range has been taken as 5.9 - $16 \mu \mathrm{mol} / \mathrm{L}$ in males, 3.36-20.44 $\mu \mathrm{mol} / \mathrm{L}$ in females. The blood counts have been analyzed with the Cell Dyn 37000 automatic blood count analyzer (Abbott park, IL, USA). Thyroid function tests have been measured with Chemiluminescent Microparticle Immunoassay in the Arcitect device (Abbott Park, IL, USA). The patients with combined folic acid and Vitamin B12 deficiencies have been excluded from the study.

The helicobacter pylori positivity, has been shown either with the fast urease test (Pronto Dry, Medical Instr, Solothurn, Switzerland) or the histopathological assessment in the patients who underwent endoscopy. The quality control measurements have been performed with Biorad External Quality Assay System 3517 in the laboratory.

The data that were gathered have been transferred to SPSS 11.01 (15 $5^{\text {th }}$ November 2001) statistical software package and analyzed with one way ANOVA and Pearson Chi square. P values that are less than 0.05 were considered as statistically significant.

\section{RESULTS}

The correlations between the vitamin B12 levels and the age, hemoglobuline, homocysteine, APA, hyper segmentation finding in peripheral blood smear, $\mathrm{MCV}$, thyroid function tests and patients with clinically diagnosed neurological problems have been depicted in table 1 . The age, MCV, hemoglobine, homocysteine, hypersegmentation in neutrophils, atrophic gastritis, positivity of helicobacter pylori, APA positivity and neurological problems are obviously higher in the group 1 , in which the vitamin B12 level has been detected lower than the $60 / \mathrm{pg} / \mathrm{mL}$. This group has been found as the eldest group with the mean age of $65.1 \pm 14.8$. When The group 1 has been compared individually to other groups, the age, hemoglobin value, MCV, level of homocysteine, APA positivity, hypersegmentation, gastric atrophy and neurological problems have been significantly different in statistical analysis $(p<0.05)$. There have been no statistically significant differences of thyroid function tests and helicobacter pylori positivity status between group 1 and other study groups $(p>0.05)$.

\section{DIscussion}

The diagnosis of vitamin B12 deficiency has been typically based on the measurements of serum levels of vitamin B12. The measurements of the methyl malonic acid and homocysteine levels that elevate in early periods of vitamin B12 deficiency have been reported as the more accurate methods for screening the vitamin B12 deficiency.

Schilling test which has been used for detecting the pernicious anemia, has been largely replaced with the serological detections of antibodies against parietal cells and intrinsic factor (10). It has been reported that the measurements are more specific if the vitamin B12 levels that are lower than $100 \mathrm{pg} / \mathrm{mL}$, in contrast to measurements are less specific in the vitamin B12 levels that are between $100-400 \mathrm{pg} / \mathrm{mL}(10,11)$. In the elevations in the levels of methyl malonic acid and homocysteine levels have been detected in 98.4 percent and in 95.9 percent of patients respectively, in a study group of 406 patients with vitamin B12 deficiency. It has been interpreted that the obvious deficiency of vitamin B12 could be ruled out clinically in patients with normal levels of homocysteine and methyl 
TABLE 1. The correlation of some hematological and biochemical parameters with the groups that have been formed according to the vitamin B12 levels.

\begin{tabular}{|c|c|c|c|c|c|}
\hline & $\begin{array}{c}\text { Group1 } \\
(n: 34)\end{array}$ & $\begin{array}{c}\text { Group2 } \\
(n: 32)\end{array}$ & $\begin{array}{c}\text { Group3 } \\
\text { (n:29) }\end{array}$ & $\begin{array}{l}\text { Group4 } \\
(n=28)\end{array}$ & $p$ \\
\hline age, year savg $\pm S D$ & $65.1 \pm 14.8$ & $61.5 \pm 18.1$ & $48.4 \pm 15.2$ & $40 \pm 13.1$ & $<0.001$ \\
\hline $\mathrm{Hb}, \mathrm{gr} / \mathrm{dl}, \mathrm{avg} \pm \mathrm{SD}$ & $8.9 \pm 2.9$ & $13.0 \pm 1.6$ & $13.3 \pm 1.4$ & $12.9 \pm 2.5$ & $<0.001$ \\
\hline $\mathrm{MCV}, \mathrm{fL}, \mathrm{avg} \pm \mathrm{SD}$ & $107.8 \pm 12.39$ & $91.4 \pm 9.7$ & $89.1 \pm 5.9$ & $86.8 \pm 3.5$ & $<0.001$ \\
\hline Hom.>16,umol/L & 85(29) & $44(14)$ & 27(8) & 18(5) & $<0.001$ \\
\hline APA (+), \%(n)\%(n) & $47(16)$ & $34(11)$ & $24(7)$ & $3(1)$ & 0.002 \\
\hline $\mathrm{HS}, \%(\mathrm{n})$ & $82(28)$ & $41(13)$ & $24(7)$ & $3(1)$ & $<0.001$ \\
\hline Ferritin, avg $\pm S D$ & $143 \pm 153$ & $55 \pm 32$ & $65 \pm 28.21$ & $48 \pm 6.8$ & $<0.001$ \\
\hline Abnormal TFT,\%(n) & $18(6)$ & $12(4)$ & $7(2)$ & $7(2)$ & 0.121 \\
\hline G. atrophy, \%(n) & $53(18)$ & $25(8)$ & $24(7)$ & $3(1)$ & $<0.001$ \\
\hline H. pylori(+), \%(n) & $41(14)$ & $40(13)$ & $45(13)$ & $43(12)$ & 0.834 \\
\hline NP\% (n) & $56(19)$ & $25(8)$ & $10(3)$ & $7(2)$ & $<0.001$ \\
\hline
\end{tabular}

Avg: average, SD: standart deviation, Hb: hemoglobin, MCV: mean erythrocyte volume, Hom: Homocysteine, APA: anti parietal antibody, HS: hypers egmentation, TFT: thyroid function tests, G. Atrophy : gastric atrophy, NP: neurological problems Group 1; B12 60 - 100 pg/mL, Group 2; B12 101-140 pg/mL, Group 3; B12 101$140 \mathrm{pg} / \mathrm{mL}$, Group 4; B12 141-178

malonic acid, since the normal values have been found in only one case. In the same study it has been detected that $28 \%$ of patients have normal hematocrite values and MCV has been found normal in $17 \%$ of the cases (12). Therefore it has been advised that the methyl malonic acid and the homocysteine levels should be utilized to diagnose the vitamin B12 deficiency in patients with low or below normal vitamin B12 levels or in the patients with neurological complaints.The elevation of at least one metabolite is $94 \%$ sensitive and $99 \%$ specific (13).

The observations that have been obtained in the current study have showed that the vitamin B12 deficiency is more specific clinically for the cases whose measurements of vitamin B12 levels are lower than $60 \mathrm{pg} / \mathrm{mL}$. The diagnosis of the real vitamin B12 deficiency should be carefully evaluated in the cases with higher levels. In a study which has been conducted in 1992, the patients with lower levels of vitamin B12 but also with normal metabolites have been reported not to respond clinically to the treatment with vitamin B12 (14). In this study it has been shown that low levels of vitamin B12 rarely could be consistent with real vitamin B 12 deficiencies. The measurement of metabolites could be useful in distinguishing the vitamin B12 and folate deficiencies. Whereas the homocysteine levels are increased in folate deficiencies, methyl malonic acid levels are not increased. The hematological disorders of folate in vitamine B12 deficiencies are being corrected with a different way which is independent from vitamin B12. The damage which is dependent on either undiagnosed or untreated vitamin B12 deficiencies, may progress in such cases (15).

The positivity of antibodies that are against to parietal cells is present in more than $90 \%$ of patients. The specificity is not favorable since it may be positive in even healthy persons. In addition, the positivity of the antibodies that are against to intrinsic factor in $70 \%$ of patients and against to thyroid gland in about $40 \%$ of patients could be seen (16).

The vitamine B12 deficiencies usually are related to three essential causes that are sourced from malabsorption, eating disorders and gastric or intestinal origin (17). The hypochlorhydria which is resulted from atrophic gastritis is the most important cause of develeopment of vitamin B12 deficiency in elderly people (18). In a study which has been performed it has been found that vitamin B12 deficiencies are related to malabsorption in 53\%, pernicious anemia in $33 \%$ and diet in $2 \%$ of elderly patients with vitamin B12 deficiencies, and the cause of vitamin B12 deficiency could not be identified in 11\% of cases (19). The incidence of Helicobacter pylori is higher in elderly patients and it may result in atrophic gastritis. Therefore, it results in decreased acid secretion and leads to vitamin B12 malabsorption (4).

The helicobacter pylori have been detected as $56 \%$ of patients in a study which has been performed in the patients with vitamin B12 deficiency, (20). It has been detected that the serum levels of vitamin B12 have been elevated in $40 \%$ of patients after the eradication of helicobacter pylori. In addition to the elevations of serum level of vitamin B12 (146-271 pg/ml), it has been detected that the levels of homocysteine have been decreased from average $41 \mu \mathrm{mol} / \mathrm{L}$ to average $13 \mu \mathrm{mol} / \mathrm{L}$ after the treatments against to helicobacter pylori (21).

In our study, it has been detected that of all the patients whose vitamin B12 levels are lower or equal than $60 \mathrm{pg} / \mathrm{ml}$, the etiology is related to pernicious anemia in $47 \%$, the rate of atrophic gastritis is $52 \%$, the infection of helicobacter pylori is positive in $41 \%$ of cases. Anti thyroid antibodies have been found positive in $17 \%$ of the patients in group 1 . In the studies that have been done, it has been recommended that the more sensitive parameters such as the levels of methyl malonic acid and homocysteine should be utilized rather than grounding solely on the serum level of vitamin B12 in the diagnosis of vitamin B12 deficiencies (11, 12, 13). The elderly patients whose vitamin B12 levels are lower than 200 pg/ml, can apply with neuropsychiatric disorders without hematological changes $(22,23)$. In our study it has been observed that neurological problems are more common in cases whose vitamin B12 levels are lower than $60 \mathrm{pg} / \mathrm{ml}$.

Among the most important findings of vitamin B12 deficiency are the morphological changes that occur in blood and bone marrow. The megaloblastic anemia is resulted from disruption of DNA synthesis. The morphological changes are observed as the macrocytosis (MCV>110 fl) in erythrocytosis and hyper- 


\section{Vitamin b12 eksikliği yönünden daha duyarlı vitamin b12 düzeylerinin, bazı hematolojik ve biyo- kimyasal parametrelerin yardımı ile belirlenmesi}

ÖZET: Vitamin B12 eksikliği genellikle yaşlı hastalarda karşılaşılan, hematolojik ve nörolojik rahatsızlara sebep olan önemli bir sağlık sorunudur. Bazı hastalarda serum vitamin B12 düzeylerinin gerçek düzeyi tam olarak yansıtmadığı düşünülmektedir. Bu çalışmamızda vitamin B12 serum düzeylerinin, bazı hematolojik ve biyokimyasal parametreleri dikkate alarak, hangi düzeylerin gerçek doku düzeylerini yansıtabileceğini amaçladık. Gereç ve Yöntem: Vitamin B12 düzeyi düşük saptanan yaşları 16 ile 90 arasında, 91'i kadın 138 hasta incelendi. Hastaların tam kan sayımı, anti parietal antikor (APA), folik asit, homosistein ve periferik yayma değerlendirmesi ile gastroduodenoskopi bulguları değerlendirildi. Bulgular: Vitamin B12 düzeyi 60 pg/mL'ın altında saptanan hasta grubunda (Grup 1), ortalama alyuvar hacmi (OEH) $105 \mathrm{FI}$ olarak bulundu. Yüksek homosistein değerleri homosistein \% 87 olguda, nötrofillerde hipersegmentasyon $\% 80$, atrofik gastrit \% 52 ve APA pozitifliği \% 45 oranında saptandı. Bu gruptaki hastaların yaş ortalamaları 65.1 olarak belirlendi. Vitamin B12 seviyesi $61-100$ pg/mL olan grupta (Grup 2) homosistein yüksekliği \% 45 , OEH $79 F I$ olduğu tespit edildi. Vitamin düzeyleri 101-140 pg/mL'ın arasındaki grupta ise (Grup 3) homosistein yüksekliği \% 21 , OEH 80 ve 141-178 pg/mL arasında olan grupta ise (Grup 4) homosistein yüksekliği \% 16 ve OEH 76 olduğu belirlendi. Grup 1 dışındaki gruplarda homosistein, APA pozitifliği, OEH ve hipersegmentasyon değerlerinin anlamlı şekilde azaldığı belirlendi. Sonuç: Bu çalışma sonucunda referans değerlerinin altındaki serum vitamin B12 düzeyinin gerçek doku düzeyini yansıtmayabileceği, vitamin B12 düzeyi 60 pg/mL ve altındaki değerlerin daha özgül olduğu saptandı.

ANAHTAR KELIMELER: Vitamin B 12, homosistein,antiparietal antikor

segmentation in neutrophils. The increases in the volume of erythrocytes may be obscured with accompanying iron deficiencies or thalassemia carrier status. Therefore the mean cell hemoglobulin (MCV) levels may be normal in the one third of the patients with vitamin B12 deficiency. It has been detected that hematocrite levels fell below the $25 \%$ of its value in only $20 \%$ of cases in a study which evaluated the patients that respond clinically to the treatment of vitamin B12 treatment (15). In our study, it has been observed that the average MCV is 108 $\mathrm{fl}$ in the group whose vitamin B12 deficiency $<60 \mathrm{pg} / \mathrm{ml}$, whereas $\mathrm{MCH}$ levels are within normal limits in other groups. While the neutrophil hyper-segmentation in real vitamin B12 deficiency is being encountered with a rate of $82 \%$, it is encountered with a lesser rate in the cases whose levels of vitamin B12 are higher. In addition it has been detected that the levels of hemoglobulin are significantly decreased in patients with low levels of tissue vitamin B12.

In conclusion, in our study study, it has been detected that the vitamin B12 levels that have been lower than reference values could not represent the real tissue levels and the values that have been measured either equal to or lower than the level of $60 \mathrm{pg} / \mathrm{dl}$ might be more specific than those have been measured higher in reference to the signaling clinical deficiencies.

\section{REFERENCES}

1. Carmel R, Green R, Rosenblatt DS, Watkins D. Update on Cobalamin, Folate, and Homocysteine. Hematology Am Soc Hematol Educ Program 1: 62-81, 2003.

2. Van Der Put NM, Steegers-Theunissen RP, Frosst P. Mutated methylene tetrahydrofolate reductase as a risk factor for spina bifida. Lancet 346:1070-1071, 1995.

3. Klerk M, Verhoef $P$, Clarke R. MTHFR $677 \mathrm{C} \rightarrow \mathrm{T}$ polymorphism and risk of coronary heart disease: a meta analysis. JAMA 288: 2023-2031, 2002.
4. Sipponen P, Laxen F, Huotari K, Harkonen M. Prevalence of low vitamin B12 and high homocysteine in serum in an elderly male population: association with atrophic gastritis and Helicobacter pylori infection. Scand J Gastroenterol 38: 1209-16, 2003.

5. Clarke R, Grimley EJ, Schneede J et al. Vitamin B12 and folate deficiency in later life. Age Ageing 33: 34-41, 2004.

6. Lechner K, Födinger M, Grisold W, et al. Vitamin B12 deficiency. New data on an old theme. Wien Klin Wochenschr. 117:579-91, 2005.

7. Wiersinga WJ, de Rooij SE, Huijmans JG et al. Diagnosis of vitamin B12 deficiency revised. Ned Tijdschr Geneeskd. 149:2789-94, 2005.

8. Antony AC. Megaloblastic anemias. Hoffman R, Benz EJ, Shattil SJ, Furie B. In: Hematology Basic Principles and Practice 3rd Ed., Churchill Livingstone Inc. Newyork, 2000, 446-484.

9. Hvas AM, Ellegaard J, Nexo E. Increased plasma methylmalonic acid level does not predict clinical manifestations of vitamin B12 deficiency. Arch Intern Med 161: 1534-1541, 2001.

10. Oh R, Brown DL. Vitamin B12 deficiency. Am Fam Physician 67: 993-994, 2003.

11. Snow CF. Laboratory diagnosis of vitamin B12 and folate deficiency. Arch Intern Med 159: 1289-1298, 1999.

12. Savage DG, Lindenbaum J, Stabler $S P$, Allen RH. Sensitivity of serum methylmalonic acid and total homocysteine determinations for diagnosing cobalamin and folate deficiencies. Am J Med 96: 239-246, 1994.

13. Hvas AM, Ellegaard J, Nexo E. Increased plasma methylmalonic acid level does not predict clinical manifestations of vitamin B12 deficiency. Arch Intern Med 161: 1534-1541, 2001.

14. Stabler SP, Allen RH, Savage DG, Lindenbaum J. Clinical spectrum and diagnosis of cobalamin deficiency. Blood 76: 871-881, 1990. 
15. Crayn, Elizabeth MD. Vitamin B12 deficiency; recognition and management. Primary Care Case Reviews 5(2): 53-60, 2002.

16. Röth A. Megaloblastaere Anaemien. Herold G. In: Innere Medizin. (c) Gerd Herold, Köln; 2007, 27-31.

17. Snow CF. Laboratory diagnosis of vitamin $B 12$ and folate deficiency: a guide for the primary care physician. Arch Intern Med 159:1289-98, 1999.

18. Stabler SP. Screening the older population for cobalamin (vitamin B12) deficiency. J Am Geriatr Soc 43:1290-7, 1995.

19. Henoun LN, Noel E, Ben AM et al. Cobalamin deficiency due to non-immune atrophic gastritis in elderly patients. A report of 25 cases. J Nutr Health Aging 9: 462, 2005.
20. Kaptan K, Beyan C, Ural AU et al. Helicobacter pylori is it a novel causative agent in Vitamin B12 deficiency? Arch Intern Med 160: 1349-53, 2000.

21. Serin E, Gumurdulu Y, Ozer B et al. Impact of elicobacter pylori on the development of vitamin B12 deficiency in the absence of gastric atrophy. Helicobacter 7: 337-41, 2002.

22. Lindenbaum J, Healton EB, Savage DG, et al. Neuropsychiatric disorders caused by cobalamin deficiency in the absence of anemia or macrocytosis. N Engl J Med 318:1720-8, 1988.

23. Lee GR. Pernicious anemia and other causes of vitamin B12 (cobalamin) deficiency. In: Lee GR, et al., eds. Wintrobe's Clinical hematology. 10th ed. Baltimore: Williams \& Wilkins, 1999, 941-64. 